\title{
Human Values and Natural Systems
}

\author{
HOLMES ROLSTON, III
}

Department of Philosophy

Colorado State University

Fort Collins, CO 80523

What human values are carried by natural systems? I can answer that question directly while I indirectly address a deeper question. Are values in nature objective or subjective? Some values (the nutrition in a potato) seem objectively there, while others (the eagle as a national symbol) seem merely assigned. Either way, certain experiences that humans find to be valuable require and are carried by natural things. As we examine the types of natural values, we can wonder whether-at times at least-value intrinsic in nature enables humans to enjoy these values.

\section{Life Support Value}

All culture remains tethered to the biosystem, and the options within built environments, though they free us by shifting our dependencies around, provide no final release from nature. Humans depend on air flow, water cycles, sunshine, photosynthesis, nitrogen fixation, decomposition bacteria, fungi, the ozone layer, food chains, insect pollination, soils, earthworms, climates, oceans, and genetic materials. Some sort of inclusive environmental fitness is required of even the most advanced culture. Humans live in a technosphere but remain residents in a biosphere.

Ecological values contribute positively to human experiences but also seem to be there apart from humans. In an evolutionary ecosystem, the central goods of the biosystemic Earth were in place before humans arrived. Humans cash in on and spend what is naturally given. In many respects, though by no means all, the earthen setup is "a happy place." Those who find value to be entirely subjective will smile and say that humans are getting back their reflected emotions, as when others say that Earth is "a lonely place." But those who think more objectively will wonder why we find ourselves alive and well (that is, happy) in a life-support system that can evolve and sustain such life.

"Happy" is too subjective a word, but what if we say that Earth is a "fortunate" or "fertile" place-with significant fortunes where life has flourished? That begins to value what is going on independently of humans. What if we say that Earth is a "satisfactory" place and mean not only that humans have prospered here but also that myriads of species have found "satisfactory" niches into which they are well fitted? Is not that objective satisfaction of life true with or without our human experiences of satisfaction? It seems parochial, uninformed ecologically, to say that our part alone in the drama establishes all its worth. Ecology is not something subjective that goes on in the human mind. Perhaps the value produced and carried in an ecosystem, together with the conscious valuing of it that comes later on, is not always a subjective affair either, although the latter does require human subjects. In an ecological perspective, that Earth is valuable 
would mean that the evolutionary ecosystem is able to produce value and has long been doing so. A late, remarkable product of the process is humans, who can claim to be of value in a unique way. When humans come, they find Earth often valuable, able to produce valued experiences. The subjective value events are a capstone subset superposed on the global, objective production and support, or carrying, of value.

Forests and soil, sunshine and rain, rivers and sky, the agelong hills, the rolling prairies, the cycling seasons-if one insists on the word, these are resources, but also they are the sources, the perennial natural givens that support everything else.

\section{Economic Value}

Though humans require natural givens, they do not take the environment ready to hand. Rather they labor, rebuilding nature to their cultural needs, owing to the remarkably flexible powers of the hand and brain. Any living thing uses its environment as a resource. A squirrel hides a cache of acorns; a bird builds a nest. But these activities take place in ecologies, hardly yet economies. Economic value in the usual sense involves deliberately redoing spontaneous natural things, coupled with a commerce in such remade things. Animals do not exchange in markets; by contrast markets are basic to every culture.

Human labor so dramatically adds value that we may be prone to devalue raw nature. "Crude" oil has no value in itself but is worth a price because a petroleum engineer may "refine" it. The sense of the re- in resource is that nature can be refitted by human labor, and the latter gives it utility. If so, we should not say, strictly speaking, that nature by itself has much or any economic value. It only carries the value of labor.

But human craft cannot produce any unnatural chemical substances or energies. All humans can do is shift natural things around, taking their properties as givens. In some sense, there is nothing unnatural about the properties of a computer or a rocket; as much as a warbling vireo or a wild strawberry both are assemblages of completely natural things operating under natural laws. This sets aside essential differences between artifacts and spontaneous nature to regain the insight that nature has economic value because it has an instrumental capacity - and this says something about the material on which the craftsmanship is expended. Nature has a rich utilitarian pliability, due both to the plurality of natural sorts and to their multifaceted powers. This is nature's economic value in a basic, etymological sense of something we can arrange so as to make a home out of it. Such economic value is partly a function of the state of science, of supply and demand, but it is also a function of available natural properties, which often unpredictably mix with human ingenuity to carry value. When humans conserve nature, we hope in the genius of the mind, but we reveal our expectations regarding the as yet undiscovered wealth of natural properties that we may some day capture and convert into economic value.

\section{Recreational Value}

It may seem frivolous to move from labor to play, from life support to recreation, but the question is a quite serious one: why humans enjoy nature even when we no longer need it for economic or life supportive reasons. For some, nature is instrumental to an active human performance; they want only terrain rough enough to test a jeep or a granite cliff 
sound enough for pitons. Even so, it serves as a field for skill. For others, the natural qualities are crucial in contemplating an autonomous performance. They watch the fleecy cumulus building over the Great White Throne in Zion, listen for the bull elk to bugle, laud the aerial skills of the hummingbird at the bergamot.

For the first group, nature is a place to show what they can do; for the other, values are reached as they are let in on nature's show - a difference surprisingly close to that between applied and pure science, to which we soon turn. These two sorts of recreational value - the gymnasium and the theater — can often be combined, as when a naturalist enjoys the exertion of a hike up a peak and also pauses at the Parry's primrose by the waterfall en route.

Recreational values can be in sports and popular pastimes and thus humanistic, but they are not always so. People like to recreate in the great outdoors because they are surrounded by something greater than anything they find indoors. When persons enjoy watching wildlife and appreciating landscapes, though this may take considerable skills, the focus is on nature as a wonderland, full of eventful drama and a bizarre repertory, a rich evolutionary ecosystem where truth is stranger than fiction.

Humans sometimes want the wild environment as an alternative to the built environment. The leisure in contrast to work for pay, the work (climbing, setting up camp) that isn't for pay, an environment with zest in contrast to a boring or familiar job, the spartan contrasts with the cited comforts-all these meet otherwise unmet needs. Here humans value the wilderness or the park noneconomically for its unbuilt characteristics. Is this only some sort of escape value? Or is there some more positive characteristic in wildness that recreates us? Are they getting away from it all? Or back to it all?

On first analysis, recreation typically benefits humans because it recreates, rejuvenates them when they are worn from work. Preserved by humans, perhaps as a park, a wilderness, a wildlife refuge, the natural world preserves human life-by recreating it. Persons go outdoors for the repair of what happens indoors. At deeper analysis there is more. Recreating in natural systems, they touch base with something missing on baseball diamonds at city park. Sometimes what they seem to be valuing is creation more than recreation.

\section{Scientific Value}

Natural science is our latest and perhaps most sophisticated cultural achievement, but we should not forget that its focus is primitive nature. Although much recent science requires elaborate analytical equipment (electron microscopes and ultracentrifuges), the subject matter of all natural science lies first and fundamentally in natural systems-the Golgi apparatus in a cell or a feldspar crystal in Precambrian igneous rock. We certainly admire scientists with their theories and instrumented intelligence, but valuing science does not devalue nature; rather, we learn something about the absorbing complexity of the natural environment when it serves as the object of such noble studies.

Natural science per se cannot be worthwhile unless its primary object, nature, is interesting enough to justify being known. To praise cognitive science is also to praise its object, for no study of a worthless thing can be intrinsically valuable. Filtering out all applied values, one reaches a residual scientific value in nature, an interest in both the natural stuff and the study of it, which has enlisted the greatest human genius.

The steaming pools of Yellowstone preserve an optimal thermal habitat for primitive anaerobic bacteria that may survive little changed from the time when life evolved under 
an oxygen-free atmosphere. Endangered fishes in the American deserts present perhaps the most striking and rapid examples of the speciation process in North America. It is typically odd, useless, and often rare things that have high scientific value. By deciphering them science helps us tell the natural tale-how things are, how they came to be. That story cannot be worthless, not only because human roots lie in it, but because we find it a delightful intellectual pursuit.

The benefits of pure science are not simply for scientists. They trickle down to all who appreciate the fauna, flora, landscapes more fully. No one sees the Grand Canyon aright unless helped by geologists. No one sees the Everglades without the benefit of geologists and botanists. Increasingly, humans valuing their natural systems want to be naturalists as well as consumers or recreators. They are birdwatchers, mineralogists, fern enthusiasts, butterfly collectors; they value a scientific appreciation of what they see because they want to value appropriately what is objectively there.

\section{Aesthetic Value}

Nature presents beauty in life and landscape-an eagle soaring, a snake slithering, the fiddleheads of ferns, purple mountains' majesties, the roar of cataracts. Yet justifying such aesthetic value verbally is as difficult as justifying the experience of pure science. The intrinsically valuable intellectual stimulation that the scientist defends is, in fact, a parallel to the aesthetic encounter that the aesthetician defends, for both demand a distance from everyday personal needs and yet a participatory experience nontransferable to the uninitiated. Sensitivities in both pure science and natural aesthetics help us see much farther than is required by our pragmatic necessities. In both, one gets purity of vision.

In culture, one appreciates human artistry-a painting, a statue. Art objects have their frames, their pedestals; plays are on stage, and fine furniture is placed with interior design. When humans value natural systems, the character of aesthetic experience is radically different. Experience is of wild nature, without artistic intent. Nothing is framed; we are not beholders of an orchestrated performance. The participant is in the midst of it all, surrounded by prairie or forest or standing on the rim of the canyon. People are challenged to do their own framing, to select what dimension of the scene to admire, how to respond to organic forms or geomorphic processes, to wind and water, smell and sound.

Sooner or later, we know an authentic sense of awe. The sense of abyss overlooking a gorge is sublime, as is the eerie chill when, nearing a stormy summit, one's hair stands on end in the charged air. All these experiences are unlikely to be had sitting in a Chippendale chair. We seldom get goose pimples before human artistry.

A prosaic person will complain that the admirer of nature overlooks chestnuts aborted by the fungal blight, fractured snowflakes, imperfections everywhere. Every natural thing is marred by accidents and eventually destroyed by them. Does not the aesthetician repair nature before appreciating it? Sometimes. But in so doing, if we consider the case of organic beauty, this sees that ideal toward which a living thing is striving and which is rarely reached in nature. So the artist paints a perfect lady-slipper orchid. In the language of geneticists, the artist portrays that phenotype producable by the normal genotype in a congenial environment. Philistines will insist that all this is not true to be plain facts of nature; poets, using a distinction going back to Aristotle, will see that this is true to the poetry of a thing, though not true to its history, and yet the poetry (the genotypic norm) directs its history (the particular individual). 


\section{Endangered Species Value}

When humans value natural systems, they want to preserve natural kinds. Congress has lamented, in the Endangered Species Act (87 Stat: 884 [1973]), the lack of "adequate concern (for) and conservation (of)" threatened and endangered species (Sec. 2). The Supreme Court said that in "language, history and structure" the Act "indicates beyond doubt that Congress intended endangered species to be afforded the highest of priorities," and this seems to recognize some good or welfare of these species, an intent to protect them from danger, even if this also reflects and coincides with "esthetic, ecological, educational, historical, recreational, and scientific value to the Nation and its people" (TVA v. Hill, 437 U.S. 153, 174 (1978)). This suggests that endangered species ought to have their place on the American continent, mixed with the values of citizens. Two-thirds of Americans believe that eagles and mountain lions ought to be protected even at cost to humans (Kellert 1979). Many hold that endangered fauna and flora have something like a biotic right to exist—at least in representative areas—for what they are in themselves.

The deepest good being preserved is the species of life itself, indeed the highest of priorities. Extinction shuts down the generative processes. What humans are doing, or allowing to happen through carelessness, is incrementally stopping the life evolved in natural systems. Every extinction is a kind of superkilling. It kills species beyond individuals, "essences" beyond "existences," the "soul" as well as the "body." It kills collectively, not just distributively. It kills the type, not just token individuals. To kill a species is to shut down a unique story, and we do not want to play the role of murderers. We have more understanding than ever of the speciating processes, more predictive power to foresee the intended and unintended results of our actions, and more power to reverse the undesirable consequences. When humans value natural systems, this generates duties to preserve, where possible, these species.

Over evolutionary time, Earth has increased its kinds from zero to five to ten million species. Several billion years' worth of creative toil have been handed over to the care of this late-coming human species in which mind has flowered and morals have emerged. Even more lately in their explosive development, humans are awakening to new duties of preservation. When humans make once-common species rare, biological vitality is lost. When humans extinguish species, they stop the story. That makes humans misfits in the system, because they bring death without survivors into Earth's prolific exuberance of life. Life is a many-splendored thing; extinction dims its luster. Living forms ought rather to persist in their struggling beauty-flourishing, pushing on at the edge of perishing.

\section{Historical Value}

Wildlands provide the profoundest historical museum of all, a relic of processes that moved the world through 99.99 percent of past time. Humans are relics of that world, and that world, as a tangible relic in our midst, contributes to our sense of duration, antiquity, and identity. An immense stream of life has flowed over these lands humans so lately inhabit and still flows (however disruptedly so) around us. The river of life is a billion years long, and humans have traveled a million years on it, recording their passage for several thousand years. Humans need living museums of natural history, a place to experience what the world was like for almost forever, before we so recently came. 
Without science we cannot know this history, as when the Yellowstone thermophiles or Archaeopteryx reveal something about the origins of life. But doing science is something else from doing history. Science is full of laws, theories, regularities, taxa, classifications, causal explanations. A historian wants more-a narrative that tells a story about what happened once upon a time, and, above all, the meanings in these events, if such there are. That is why science cannot teach us all we need to know about nature. Indeed interpretive natural history is quite a demanding inquiry. Here humans evaluate the story in which they stand and write the current chapter in the ongoing Earth narrative.

Using nature to teach natural history is a sort of instrumental value, but here the living wildland museum and the historical reality are one and the same. When we treasure the living museum instrumentally, we may also come to recognize intrinsic value in the natural processes.

Wildlands further provide historical value for the cultures superimposed on natural history. Americans (North, South, Canadian, Central) have a recent heritage of self-development against a diverse and challenging environment, seen in pioneer, frontiersman, cowboy, and gaucho motifs. New World cultures remain close to the memory of a primitive landscape. The American's ancestral virtues were forged with the European invasion of a (so-called) "empty" continent, which it was their "manifest destiny" to develop. Nor should we forget the "red" years, before the "white" years. Europeans as well have historical memories associated with nature-the British with the moors, the Germans with the Black Forest, the Russians with the steppes. Every culture remains resident in some environment.

Forests, prairies, and ranges ought to be preserved as souvenir places for each generation of Americans learning (however secondarily or critically) their forefathers' moods, regained there quite as much as in the Minuteman Historical Park. Such places provide a lingering echo of what we once were, of a way we once passed. Without these memories we cannot know who and where we are. A person without a country is a tragedy indeed.

\section{Cultural Symbolization Value}

The bald eagle symbolizes American self-images and aspirations (freedom, strength, beauty), as does the bighorn ram, a "state animal" for Coloradoans. The pasqueflower is the state flower of South Dakota, the moose a symbol for Maine, the maple leaf for Canada. The lion is a British symbol; the Russians have chosen the bear. Natural areas enter local cultural moods-Grandfather Mountain in western North Carolina, Natural Bridge and the Shenandoah River in central Virginia. Every homescape has its old and familiar haunts — swimming holes, water gaps, passes — which enter our sense of belongingness and identity. Culture commingles with landscape and wildlife in places named after geomorphic, faunal, or floral features: Tinkling Springs, Fox Hollow, Aspen, and Crested Butte.

However much the native wildness is domesticated, humans want some wildness preserved, for it comes to express the values of the culture superimposed on it. What would be the impact on American hopes if the bald eagle became extinct? On New Hampshire with the loss of the Great Stone Face? What are the psychological connections between the Mississippi River and the state of Mississippi? Between the Scots and Loch Lomond? Would not the death of the last bighorn lower the perceived quality of life in Colorado? Would Boulder, Colorado, not be a poorer place with the Flatirons scarred from development? What would Florida be without its flora? 
No culture develops in independence of the environment on which it is superimposed, no matter how relatively free humans are in their cultural options, no matter that the Chickahominies and the English did very different things in Virginia. In culture, there is but one Virginia, and each Virginian has a proper name. The human differences include conscious self-affirmations and heritages for which nature provides little precedent. But nature first is never twice the same, and the idiographic features in nature blend with those in culture to particularize and enrich the combined story. Always in the understory there are distinctive landscape features - the Shenandoah Valley or the Chesapeake Bay-with which the Virginians interact. The cultural symbolization capacity of nature is no accident but has been a repeated feature in the myriad cultures on Earth.

\section{Character-Building Value}

Wildlands are used by organizations that educate character-Boy and Girl Scouts, Outward Bound, and church camps. Similar growth also occurs in individuals independently of formal organizations. The challenge of self-competence, in teamwork or alone, is valued, together with reflection over skills acquired and one's place in the world. Wildlands provide a place to sweat, to push yourself more than usual, perhaps to let the adrenalin flow. They provide a place to take calculated risks, to learn the luck of the weather, to lose and find one's way, to reminisce over success and failure. They teach one to care about his or her physical condition.

Wildlands provide a place to gain humility and a sense of proportion. The virtues of humility, simplicity, frugality, serenity, and independence can also be learned in town. But they are nowhere better taught than in encounter with nature. This recapitulates partly our historical experience; it anticipates the religious experience that we soon examine. What was earlier a recreational testing of what we can do is heightened into an achievement of self-identity. In a survey of three hundred geniuses, Edith Cobb found characteristic of their youth evocative experiences in natural locales, a formative factor in their creativity (Cobb 1959, 1977). Many people have reported how self-actualization was fostered in a wilderness setting. Nature is a place to "know thyself."

Related to this is a therapeutic value in nature. Nature is a setting to treat psychologically disturbed persons. For some who are mentally ill, the ambiguity and complexity in culture can be disorienting. It is hard to discriminate among friends, enemies, and the indifferent, hard to get resolve focused on what to do next or to predict the consequences of delay. But in the wilds or on the farm, supper has to be cooked; one needs firewood and it is getting dark. There are probabilities in facing nature; maybe it won't rain when you forget your poncho. But there are no ambiguities. Exertion is demanded; visceral accomplishment is evident in a low-frustration environment. The self is starkly present, and the protocol is simpler. One really is on his own; or, one's friends are few, and she utterly depends on them. All this can mobilize the disturbed for recovery, using in basic form the same forces that create the character-building effect for us all.

So far as humans have been selected over the evolutionary epic to need challenge, adventure, exertion, and risk, society must either provide avenues for such archetypal emotions or expect deviant behavior-gangs and rebels without a cause. There are alternative routes for such expression—sports, for instance, or, alas, the military. Humans are remarkably unspecialized. But perhaps wild and rural areas provide a "niche" that matches some deep-seated psychosomatic needs. The lack of this may be part of the trouble in our crowded, warring world. We do not know but can suspect that encounter with nature is often related to our mental health. 


\section{Diversity-Unity Values}

The sciences describe much natural diversity and also much unity, terms that are descriptive and yet contain dimensions of value. The physical sciences have revealed the astronomical extent of matter while reducing it into a few kinds of elements and particles, which dissolve into wave fields. The taxonomist has enlarged the array of natural kinds, while the biochemist has found only the materials of physics organized in basic chemistries, such as the citric-acid cycle or DNA and RNA at the core of life. Evolution has traced every life form back to monophyletic or a few polyphyletic origins, while ecology has interwoven these myriad forms to connect them at present as fully as they have been related by paleontology. This macroscopic web is matched by the unity revealed by the electron microscope or the X-ray spectrometer. The natural pageant is a kind of symphony of motifs, all spun from a few simple notes.

The story of science is the discovery of a bigger universe with more things in it and the finding of laws and structures to explain their common composition and kinship. A few centuries ago we supposed this universe to have far less spatiotemporal and biological diversity, and its unity was unknown or denied. Everywhere there was dualism and opposition - in heaven and earth, mind and matter, life and nonlife, humans and nature, gods and demons. No naturalist today would return to that universe, if he or she could, for it was oppressively small, less diverse, and yet also superstitious and lacking in the natural unity that we now know it to possess.

Notice how both this diversity and unity feed the human mind. Mind cannot be formed under the homogeneity of a blank wall nor before the heterogeneity of a bewildering jungle. A complex mind evolves in order to deal with a diverse world, yet one through which unifying relationships run. Do we then say that these features are of no value until thickened by the addition of human interest? Or do we wonder that just this system, evolving so, did thicken human interest to form the mind prehistorically and that it continues to do so now? The mind is a mirror of these properties in nature, and there is even a sense in which the mind, founded on the cerebral complexity and integrating capacity, is a product of nature's inclination both to diversify and to unify.

\section{Stability and Spontaneity Values}

A pair of complementary natural values mixes ordered stability with spontaneity, counterparts that are descriptive and also valuational. That natural processes are regular-that gravity holds, oaks breed in kind, and succession is repeated-yields laws and trends rooted in the causal principle, and means that natural systems are dependable, as well as unified and intelligible. Every order is not a value; but a requisite of any universe is that it be ordered, and we need not despise a necessary good. Nor does such minimum essential order account for the ecological and biochemical constancy that supports life and mind, upon which all human knowledge, security, and values depend.

The polar value, really a sort of freedom, is hardly known to science by any such name. Still, nature sometimes provides an "appearance" of contingency. Neither landscapes, nor aspen leaves, nor ecological successions are ever twice the same. What happens in field and forest is always something of an adventure, as the way the cottontail evades the coyote, or just when the last leaf is tossed from the maple and where the gusting wind lands it. Determinists insist that nothing in nature (or culture) can be either 
of chance or of choice, believing that to say otherwise is to destroy the fundamental axiom of all science. But others require a less rigidly closed system, finding that science still prospers when positing statistical laws, which need not specify every particular.

Each wild area is one of a kind, so we give it a proper name - the Rawah Mountains, the Dismal Swamp. Even when exploring some nameless canyon, one experiences a concrete locus never duplicated in idiosyncratic detail. We do not want order at the expense of spontaneous novelty, too much system and too little story. We want constancy with contingency. The regularity is valuable, but so is this element of wildness. Just this wildness in natural systems, which might threaten to make nature chaotic, in fact adds novelty. By making each location different, wildness makes a favorable difference. It makes each ecosystem historic, the more excellent because no two are alike.

We are not sure whether Australopithecus had to develop in Africa or whether giraffes had to develop long necks, although both events may have been probable. For the conservatives, it is safest to say theoretically that here we only reveal our ignorance of nature's detailed determinism, that nature's surprises are only apparent, though perhaps we cannot now or ever escape this appearance. For the liberals, it is bolder and more satisfying, as well as true to practical experience, to say that natural systems allow the real appearance of spontaneous novelty. The Darwinian revolution revised the Newtonian view to find nature sometimes a jungle and not a clock, and many have disliked this. Contingencies do put a bit of chaos into the cosmos. But you can have a sort of adventure in Darwin's jungle that you cannot have in Newton's clock. This openness brings risk and often misfortune, but it sometimes adds excitement. Here nature's intelligibility, aesthetic beauty, dependability, and unity are enriched by the presence of spontaneity, and this can be valued too.

\section{Dialectical Value}

We humans are not really bounded by our skin, but life proceeds in environmental dialectic. The hands have evolved for grasping natural things, but so has the brain, and sentient experience underruns mental life. The crafting of an arrow point, a rifle, or a rocket is an environmental exchange. Culture is carved out against nature, but carved out of nature, and this is not simple to handle valuationally. Superficially, we first say that the helps in nature are good, the hurts bad. So far as nature is antagonistic and discomforting, it has disvalue. With deeper insight, we do not always count environmental conductance as good and environmental resistance as bad, but the currents of life flow in their interplay.

An environment that was entirely hostile would slay us; life could never have appeared within it. An environment that was entirely irenic would stagnate us; human life could never have appeared there either. Our culture, in which our classical humanity consists, and our science, in which our modern humanity consists, has originated in the face of oppositional nature. Nature insists that we work, and this laboring and even suffering is its fundamental economic pressure. The pioneer, pilgrim, explorer, and settler loved the frontier for the challenge and discipline that put fiber into the American soul. One reason we lament the passing of wilderness is that we do not want entirely to tame this aboriginal element in which our genius was forged.

But this is of a piece with the larger natural process of conflict and resolution. Half the beauty of life comes out of it-flowers, fruits, shells, scales, muscles, hair, locomo- 
tion, perception, endurance. The cougar's fang sharpens the deer's sight, the deer's fleet-footedness shapes a more supple lioness. We admire this element of fight even in the maimed and blasted, even in the inanimate, gnarled timberline fir. The coming of Darwin is often thought to have ruined nature's harmonious architectures, but the struggles he posits, if sometimes overwhelming, are not always valueless. None of life's heroic quality is possible without this dialectical stress. Take away the friction, and would the structures stand? Would the system move?

Do we then say that humans only wrest values instrumentally from intrinsically valueless nature? Has this dialectical context of life and mind no systemic value? That humans should struggle against storm and winter is not here denied, nor that we may need to oppose wolves and thistles, rattlesnakes and malaria mosquitos. But we add that humans can value the alien in nature not only in its autonomous otherness, but even in its stimulus, provocation, and opposition. We owe all culture to the mixed support and hostility of nature; the one is the warp, the other the woof in the weaving of what we have become.

\section{Life Value}

John Muir would not let Gifford Pinchot kill a tarantula at the Grand Canyon, remarking that "it had as much right there as we did" (Pinchot 1947, 103). A thoroughgoing humanist may say that only personal life has intrinsic value, making every other life form instrumental to human interests, but a sensitive naturalist will suspect that this is a callous rationalization, anthropocentric class self-interest. The first lesson learned in evolution was perhaps one of conflict, but a subsequent one is of kinship, for the life we value in persons is advanced from but allied with the life in monkeys, perch, and wildflowers.

A plant is a spontaneous life system, self-maintaining with a controlling program. It executes this project, checking against performance in the world, using feedback loops. It composes and recomposes itself, maintaining order against disordering tendencies. Plants do not have ends in view. They are not subjects of a life, and in that familiar sense, they do not have goals. Yet each plant develops and maintains a botanical identity, posting a boundary between itself and its environment. An acorn becomes an oak; the oak stands on its own.

This botanical program is coded in the DNA, informational core molecules, without which the plant would collapse into the humus. The genetic set is thus really a normative set; it distinguishes between what is and what ought to be. This does not mean that plants are moral agents. But the organism is an evaluative system, selecting resources for itself. The plant grows, reproduces, repairs its wounds, and resists death. All this, from one perspective, is just biochemistry - the whir and buzz of organic molecules, enzymes, proteins. But from an equally valid - and objective-perspective, the morphology and metabolism that the organism projects is a valued state. A life is spontaneously defended for what it is itself, without necessary further contributory reference, although in ecosystems such lives necessarily do have further reference. The plants don't care, so why should I? But plants do care-using botanical standards, the only form of caring available to them. The plant life per se is defended-an intrinsic value.

To put this in the language of conservation biology, a plant is already engaged in the biological conservation of its identity and kind, long before conservation biologists come on the scene. What humans who value nature ought to do is respect plants for what they are in themselves-natural systems of conservation biology. 


\section{Religious Value}

Nature generates poetry, philosophy, and religion, and at its deepest educational capacity we are awed by staring into the stormy surf or peering down at the reversing protoplasmic stream in a creeping myxomycete plasmodium. Mountaintop experiences, sunsets, canyon strata, or a meadow of dogstooth violets can generate experiences of "a motion and spirit that impels ... and rolls through all things (Wordsworth 1798). For wilderness purists intensely, and for most people occasionally, wildlands provide a cathedral setting. The wilderness elicits cosmic questions, differently from town. Humans are programmed to ask why, and the natural dialectic is the cradle of our spirituality. The wilderness works on a traveler's soul as much as it does his muscles.

We might say, overworking the term, the nature is a religious "resource." Using a better word, we want a wilderness "sanctuary," a sacrosanct, holy place, where we draw near to ultimacy. Nature used as school for character is clearly an instrumental use, but what shall we say when nature is used as church? Is this too in instrumental use to generate human religious experiences, nothing more? Perhaps. But some of these experiences will recognize God's creation, or the Ultimate Reality, or a Nature sacred in itself. In fact, one profanes such experience and nature alike to see nature as merely instrumental and otherwise devoid of value.

Take the natural symbols_-light and fire, water or rock, morning and evening, the warmth of summer and the cold of winter, the flowers of spring and the fruits of fall, rain and rivers, seeds and growth, earth and sky. How readily we put these material phenomena to "metaphorical" or "spiritual" use, when we speak of life's "stormy weather," of strength of character "like a rock," or insecurity "like a shifting sand," of the "dark cloud with the silver lining." How profound are the psychological forces stirred within us the gray and misty sky, the balmy spring day, the quiet of a snowfall, the calling of loons. How the height of mountains "elevates" us, and the depths of the sea stimulates "deep" thoughts within!

Bread, water, wine, paths, fatherhood, motherhood, mountains, rivers, light, and darkness - these are not incidentally among our richest sacramental elements. The struggling life essence emerging overlaid on physical existence, the arrival of intelligence and whether it has any evolutionary point, the complementarity of spirit and matter-these remain puzzles never completely worked out; they point to something greater. We can count that a disvalue; nature outgoes and disappoints us. We can even count it a value that nature breeds a creative discontent and is so rich and demanding as to be at length inaccessible in the whole, knowable only in part. We are kept pilgrims and pioneers on a frontier, and to travel hopefully is better than to arrive. Meanwhile, this much at least we do value: that nature is endlessly stimulating to the mind, and bores only the ignorant or the insensitive.

\section{Human Owners and Natural Values}

Are values in nature subjective or objective? If humans are to talk about natural values, we must be actively "in on" them, that is, "share" those values in subjective, personal experiences adequate to judge them. Even scientists now realize that they always bear some relationship beyond that of passive observer to whatever they seek to know. But the ownership features loom larger here. Humans valuing natural systems are rather more 
"turned on" than in making straightforward empirical judgments, but this can mean that we are rather more "tuned in" with what is so. It would be valuational solipsism to conclude that in those values natural things seem to carry we are getting back absolutely nothing but our projections. Values are met in real natural things, which seems to warrant the view that valuing is sometimes a form of knowing where humans register objective properties in the appreciating mind, notwithstanding what we may add in the appreciating process. Otherwise we commit the fallacy of misplaced location and ascribe to the viewer what is really in the scene, or at least what comes relationally.

We might first think that the phrase "experienced value" is a tautology and the phrase "unexperienced value" a contradiction in terms, somewhat like the phrases "experienced thought" and "unexperienced thought." But the existence of unexperienced value is not a contradiction in terms, unless one builds into the meaning of value that it must be experienced. Humans must come to own any values about which they deliberate. We participate in them and realize that we are enjoying them. But it would be fatal to understanding the objective values carried by natural systems to conclude that since humans experientially own these values, values are found only in felt existence, nothing more.

Value is not received as the conclusion of an argument, or by the indifferent observation of a causal series. A value or disvalue recognized as whatever has got some bite to it. That brings emoting, and we may be tempted to say that the marriage of a subject to its object gives birth to value. Value enters and exits with awareness. Doing science and taking holidays, for instance, are human experiences. So it might seem that any associated value lies entirely in the human experiences, no matter how greatly features in nature contribute to it. On the other hand, life support and genetic information operate in the wild regardless of whether humans are present or aware of these things. Perhaps the human valuing of nature generates new levels of values, a kind that are experiential by logical necessity, but these seem superimposed on spontaneous natural values, some kinds of which are not experiential.

If natural things have values, we cannot conceivably learn this without experiences by which we are let in on them. With every such sharing there comes a caring, and this may seem to proscribe objective neutrality. In fact, it only prescribes circumspect inquiry. All natural science is built on the experience of nature, but this does not entail that its descriptions, its "facts," are just those experiences. All valuing of nature is built on experience too, but that does not entail that its descriptions, its "values," are just those experiences. Value must be lived through, experienced, but so as to discern the character of the surroundings one is living through.

A powerful emotion when leaving culture to return to nature is the sense of entrance into a natural place flourishing independently of any human presence. The forces by which natural systems run are not human forces; they are the biological and physical forces that have generated the world. Wild creatures are selected for their fitness in the places they inhabit; the wilderness is a complex tapestry of values, with each living thing defending itself, with vital needs, and the whole system a network in which goods are circulated round and integrated into other goods through both conflict and complementarity.

Nature is a vast scene of birth and death, springtime and harvest, permanence and change, of budding, flowering, withering away, of pain and pleasure, of success and failure, of beauty giving way to ugliness and again to beauty. Contemplating it all, there come moments of truth valuing life's storied achievements, transient and sustained over chaos. There is a music to it all, and not least when in a minor key. The natural history 
that envelops us is of value, not only because we humans place value there, but because value there is endorsed by the signature of time and eternity.

\section{References}

Cobb, E. 1959. The ecology of imagination in childhood. Daedalus 88:537-48.

Kellert, S. R. 1979. Public attitudes toward critical wildlife and natural habitat issues. Phase One. Washington, D.C.: U.S. Fish and Wildlife Service.

Pinchot, G. 1947. Breaking New Ground. New York: Harcourt, Brace.

Wordsworth, W. 1798. Lines composed a few miles above Tintern Abbey. 